\title{
Zur Zitierweise
}

Zitate und Verweise im Text werden mit dem Erscheinungsjahr und der Seite der Quelle genannt; die Angaben beziehen sich durchgehend auf das Literaturverzeichnis S. $245 \mathrm{ff}$. 